\title{
CORPORATE TAX POLICY, FoREIGN FIRM OWNERSHIP AND THIN CAPITALIZATION
}

\author{
Clemens Fuest \\ THOMAS HEMMELGARN
}

CESIFO WORKING PAPER NO. 1096

CATEGORY 1: Public FinANCE

DECEMBER 2003

An electronic version of the paper may be downloaded

- from the SSRN website:

- from the CESifo website: www.CESifo.de 


\title{
CORPORATE TAX POLICY, FOREIGN FIRM OWNERSHIP AND THIN CAPITALIZATION
}

\begin{abstract}
This paper analyzes the implications of foreign firm ownership and international profit shifting through thin capitalization for corporate tax policy. We consider a model of interjurisdictional tax competition where the corporate tax serves as a backstop to the personal income tax, interest on debt is deductible from the corporate tax base and multinational firms may shift profit across countries through thin capitalization. We show that the problem of thin capitalization induces countries to reduce their corporate tax rates below the personal income tax rate and to broaden their tax bases. Moreover, foreign firm ownership leads to a reduction in corporate tax rates. We also show that there is scope for welfare enhancing tax coordination in our model. In the presence of both foreign firm ownership and thin capitalization, countries gain from a coordinated increase in corporate tax rates or from a coordinated broadening of the tax base.
\end{abstract}

JEL Classification: H21, H77, G32.

Keywords: tax competition, income shifting.

Clemens Fuest

Seminar für Finanzwissenschaft

Universität zu Köln

Albertus-Magnus-Platz

$50923 \mathrm{Köln}$

Germany

clemens.fuest@uni-koeln.de
Thomas Hemmelgarn

Seminar für Finanzwissenschaft

Universität zu Köln

Albertus-Magnus-Platz

50923 Köln

Germany

thomas.hemmelgarn@uni-koeln.de

We thank two anonymous referees for their valuable comments. The usual disclaimer applies. 


\section{Introduction}

In recent years, corporate tax policy in most industrialized countries has been characterized by a trend towards lower tax rates and broader tax bases. In the literature, this trend has been explained as a reaction of national tax policies to border crossing capital mobility and an increasing importance of multinational firms. There are several reasons why the existence of multinational firms is thought to have an impact on national corporate tax systems. ${ }^{1}$

Firstly, when making their location decisions for investment projects, these firms usually consider locations in different countries. Tax considerations are of course not the only factor determining these location decisions, but they are an important one. From the perspective of national tax policy, this gives rise to competitive pressure as countries try to attract firms.

Secondly, multinational firms may shift profits across countries without changing the location of their real investment. This may be done either via transfer price manipulation (Haufler and Schjelderup (2000)) or thin capitalization, where firms increase the amount of debt financing in high tax countries in order to benefit from the deductibility of interest from the corporate tax base (Mintz and Smart (2001)). It is intuitive that international profit shifting also leads to downward pressures on national corporate tax rates.

A third important characteristic of multinational firms is that the ownership of these firms usually spreads over many countries. This implies that multinational firms often operate in countries other than those where their owners reside. Foreign firm ownership is usually thought to act as a break on the downward pressure on corporate tax rates caused by tax competition (Huizinga and Nielsen (1997)).

This paper reconsiders the implications of foreign firm ownership and international profit shifting through thin capitalization for corporate tax policy. The analysis leads to three main results. Firstly, it turns out that foreign firm ownership leads to a reduction rather than an increase in corporate tax rates. Secondly, the existence of international profit shifting through thin capitalization induces countries to reduce their tax rates and to broaden their tax bases. Thirdly, we show that there is scope for welfare enhancing tax coordination in our model. In the presence of both foreign firm ownership and income shifting through debt, countries gain from a coordinated increase in corporate tax rates or from a coordinated broadening of the tax base.

How are these findings related to the existing literature? The papers most closely related to our analysis are Haufler and Schjelderup (2000), Bond (2000) and Huizinga and Nielsen (1997, 2002). Haufler and Schjelderup (2000) consider a model where firms earn supernormal profits and may manipulate transfer prices to shift profits across countries. In the absence of profit shifting, countries would levy a cash flow tax which avoids a distortion of marginal investment but taxes pure profits at a confiscatory rate of $100 \%$. However, if firms may shift income across jurisdictions, they can avoid the confiscatory taxation of pure profits, so that countries are forced to reduce their tax rates. As a result, pure profits are partly untaxed. Given this, it is optimal to tax these profits indirectly by broadening the tax base, even at the cost of distorting domestic investment. Bond (2000) argues that multinational firms often face a discrete investment choice. For instance, this may be the choice between serving a domestic market either by producing in the country or by locating in another country and serving the domestic market via imports. This implies that the average rather than the marginal tax rate becomes relevant for the location decision. If, in addition, an investment project generates supernormal profits, high statutory rates may deter investment despite generous depreciation

\footnotetext{
${ }^{1}$ For a survey on the taxation of multinational firms see Gresik (2001).
} 
allowances. Both papers thus provide an explanation for the observed tax rate cut cum base broadening policies. ${ }^{2}$

Our analysis differs from these papers in several respects. Firstly, our model does not rely on the existence of pure profits so that the corporate income tax does not have the function of taxing pure profits. Secondly, we consider income shifting through debt, rather than transfer pricing. Thirdly, the reasons for and the effects of tax rate cut cum base broadening policies are different in our model. In particular, the broadening of the tax base in Haufler and Schjelderup (2000) deliberately distorts domestic investment, whereas the broadening of the tax base in our model aims at restoring production efficiency.

Our result that foreign firm ownership reduces corporate tax rates is diametrically opposed to the findings in Huizinga and Nielsen (1997), who find that foreign firm ownership tends to increase corporate taxes. The reason for this difference in results is that, in our model, the corporate tax has the function of serving as a backstop to personal income taxes while the corporate tax in Huizinga and Nielsen (1997) is effectively a tax on economic rents. In their model, these rents partly accrue to foreigners. Therefore host countries have an incentive to raise their corporate tax rates above the level they would choose in the absence of foreign firm ownership. ${ }^{3}$ Huizinga and Nielsen (1997) also find that a coordinated reduction of corporate taxes increases welfare in their model whereas our analysis leads to the opposite result. Huizinga and Nielsen (2002) extend the model in Huizinga and Nielsen (1997) by considering the case where residence based taxes on portfolio investment cannot be implemented. In this framework, it turns out that the welfare effect of a coordinated reduction of tax rates becomes ambiguous. ${ }^{4}$

The rest of the paper is set up as follows. In the next section, we present the model. In section 3, we analyze the optimal tax policy under tax competition, under different assumptions on foreign firm ownership and the availability of income shifting opportunities. Section 4 considers the potential for welfare enhancing tax coordination. Section 5 concludes.

\section{The Model}

Consider a union of $n$ small open economies. Capital is internationally mobile both within the union and between the union and the rest of the world. Each country in the union is the home country of many internationally immobile households and hosts real investment of a large number of multinational firms. For notational convenience, the number of households per country and the number of multinational firms are normalized to unity.

\footnotetext{
${ }^{2}$ A third, information based explanation for tax rate cut cum base broadening policies is suggested by Osmundsen, Hagen, and Schjelder up (1998), who consider a world where firms face different mobility costs and the government cannot observe firm specific mobility. In this framework, it turns out that a corporate tax system with broad bases and low tax rates improves the incentives for firms to reveal their true type.

${ }^{3}$ Olsen and Osmundsen (2001) derive a similar result in an imperfect information setting. Kind, Midelfart, and Schjelderup (2003) find the same effect of foreign ownership in a model with trade costs.

${ }^{4}$ Foreign ownership of domestic factors of production is also analysed by Richter and Wellisch (1996), in the context of household mobility, and by Wildasin and Wilson (1998), who show that confiscatory taxation of rents in the presence of foreign firm ownership may hinder risk diversification.
} 


\subsection{Households}

Households live for two periods. In the first period, they receive an exogenous endowment $E$ and a dividend $D_{1}{ }^{5}$ which may be used for first period consumption $C_{1}$ or savings $S .{ }^{6}$ The first period budget constraint is

$$
E+D_{1}=C_{1}+S
$$

In the second period, the household supplies $L$ units of labour and receives another dividend $D_{2}$. The second period budget constraint is

$$
C_{2}=(1+r(1-t)) S+D_{2}+w(1-T) L
$$

where $C_{2}$ is second period consumption, $r$ is the interest rate in the international capital market, $t$ is the tax rate on savings, $w$ is the wage rate and $T$ is the tax rate on labour income. The household's utility function is given by $U\left(C_{1}, C_{2}, L\right)$ and has the usual neoclassical properties. Denote the present value of the dividends accruing to the domestic household by $P$. Using

$$
P=D_{1}+\frac{D_{2}}{(1+r(1-t))}
$$

and defining savings net of dividends received in period 1 as $S^{*}=S-D_{1}$, we can write the budget constraints in (1) and (2) as

$$
E=C_{1}+S^{*}
$$

and

$$
C_{2}=(1+r(1-t))\left(S^{*}+P\right)+w(1-T) L
$$

The household maximizes $U\left(C_{1}, C_{2}, L\right)$ subject to (3) and (4). This yields the standard results

$$
\frac{\partial U}{\partial C_{1}}-\frac{\partial U}{\partial C_{2}}\left(1+r^{n}\right)=0
$$

and

$$
\frac{\partial U}{\partial C_{2}} w^{n}+\frac{\partial U}{\partial L}=0
$$

where $w^{n}=w(1-T)$ and $r^{n}=r(1-t)$. (5) and (6) define the (modified) savings function $S^{*}=S^{*}\left(r^{n}, w^{n}, P\right)$ and the labour supply function $L^{s}=L^{s}\left(r^{n}, w^{n}, P\right)$. The household's indirect utility function is denoted by $V\left(r^{n}, w^{n}, P\right)$ and has the properties $V_{1}\left(r^{n}, w^{n}, P\right)=$ $\lambda\left(S^{*}+P\right), V_{2}\left(r^{n}, w^{n}, P\right)=\lambda L, V_{3}\left(r^{n}, w^{n}, P\right)=\lambda(1+r(1-t))$, where $\lambda$ is the marginal utility of second period income.

\section{$2.2 \quad$ Firms}

We assume that the representative multinational firm is endowed with retained earnings $R$ and that it operates in each of the $n$ countries in the union. In each country $j, j=1 . . n$, the firm invests $K_{j}$ in period 1 . In period 2, the firm employs $L_{j}$ units of labour in each country and produces an output $F\left(K_{j}, L_{j}\right)+K_{j}$. We assume that $F\left(K_{j}, L_{j}\right)+K_{j}$ is linear-homogenous in $K_{j}$ and $L_{j}$.

\footnotetext{
${ }^{5}$ We abstract from dividend taxes, for reasons which will be discussed further below.

${ }^{6}$ In order to reduce notation, we drop country indices if possible.
} 
The firm's investment may be financed by retained earnings or debt. New equity as a source of finance is ruled out. ${ }^{7}$ Retained earnings which are not used to finance investment are distributed to the owners. The firm's profit distribution in period 1 is given by $\pi_{1}=R-$ $\sum_{i=1}^{n}\left(1-\alpha_{i}\right) K_{i}$, where $\alpha_{j}$ is the share of investment in country $j$ financed by external debt. ${ }^{8}$

Next to external debt, the firm may also use internal debt. The main difference to external debt is that internal debt does not increase dividend distributions. Internal debt is used to avoid corporate taxes. Rather than using equity to finance investment directly, the firm may endow a subsidiary in a tax haven country which we assume to be a country outside the union with equity. The subsidiary then borrows its funds back to the parent company. ${ }^{9}$ This implies that corporate income takes the form of interest payments, which are deductible from the corporate tax base. To make things simple, we assume that the corporate tax rate in the tax haven country is zero. Moreover, in all countries, foreign profits are assumed to be exempt from domestic corporate tax, so that profits of the subsidiary in the tax haven can be repatriated tax free. ${ }^{10}$ Under these assumptions, the firm's reduction in tax costs from replacing one Euro of equity in country $j$ by internal debt is simply equal to the country's corporate tax rate $\tau_{j}$. In the following, we denote the share of internal debt in the firm's investment in country $j$ by $\sigma_{j}$.

Apart from tax considerations, there are nontax costs and benefits associated with the financial structure of firms. We assume that the nontax costs and benefits of financing in our model can be summarized in a cost function which is given by $r \sum_{i=1}^{n} \Psi\left(\alpha_{i}, \sigma_{i}\right) K_{i}$, where $\Psi(\alpha, \sigma)$ is a function with the following properties: $\Psi_{\alpha}\left(\alpha^{*}, \sigma\right)=0, \Psi_{\alpha}(\alpha, \sigma)>0$ if $\alpha>\alpha^{*}, \Psi_{\alpha}(\alpha, \sigma)<0$ if $\alpha<\alpha^{*}$ and $\Psi_{\alpha \alpha}(\alpha, \sigma)>0$, where $0<\alpha^{*}<1$. Moreover, we assume that $\Psi_{\alpha \sigma}(\alpha, \sigma)=0, \Psi_{\sigma}(\alpha, 0)=0, \Psi_{\sigma}(\alpha, \sigma)>0$ if $\sigma>0, \Psi_{\sigma}(\alpha, \sigma)<0$ and if $\sigma<0$ $\Psi_{\sigma \sigma}(\alpha, \sigma)>0$. These assumptions essentially imply that there is a share of external debt $\alpha^{*}$ which is optimal in the absence of taxes, given $\sigma$. Of course, without taxes, we also have $\sigma=0$. If firms deviate from $\alpha=\alpha^{*}$ and $\sigma=0$, they face increasing marginal nontax costs of distorting their financial structure.

Given that the function $\Psi(\alpha, \sigma)$ is important for the following analysis, it is necessary to justify the assumptions made on $\Psi(\alpha, \sigma)$, in particular the convexity in $\alpha$ and $\sigma$. The assumption that $\Psi(\alpha, \sigma)$ is convex in $\alpha$ follows Mintz and Smart (2002) and may be interpreted as a result of informational asymmetries between outside investors and managers of the firm. For instance, of there is too little external debt, managers may use the firm's cash flow to pursue empire building strategies (Hart (1993)). An increase in external debt reduces the cash flow controlled by managers. But if there is too much debt, the firm may go bankrupt,

\footnotetext{
${ }^{7}$ This is in line with the empirical fact that the role of new equity for the financing of investment is small, see e.g. Bond (2000).

${ }^{8}$ Note that the dividend which accrues to the representative household in country $j$ in period 1 is given by $D_{1 j}=\beta_{j} \pi_{1}$, where $\beta_{j}$ is the share in the multinational firm's equity owned by the household in country $j$.

${ }^{9}$ Real world tax avoidance through internal debt will of course be more subtle but the model captures the essentials of the process. Often, tax avoidance through thin capitalization involves so-called "double dip" transactions, where the funds used to endow for eign subsidiaries are borrowed in high tax countries to generate additional interest deductions, see Fuest, Huber, and Mintz (2003).

${ }^{10}$ One might object here that exemption may be denied for profits repatriated from tax haven countries which have no double taxation agreements with the country where the parent company resides. But tax avoidance through internal debt is also possible by using special tax arrangements offered by countries covered by double taxation agreements. One example is the Belgian Financial Coordination Center (Malherbe (2002)). Even if exemption is denied, the deferral of tax obligations may be sufficient as an incentive to use internal debt as an income shifting device. For an analysis of tax competition where for eign profits are taxed according to the credit system or the deduction system see Fuest and Huber (2002).
} 
which gives rise to bankruptcy costs. Consider next the cost associated with internal debt. In the theoretical literature on the economic role of internal debt, the view is widespread that internal debt is primarily a tax saving instrument (see e.g. Chowdhry and Nanda (1994) and Chowdhry and Coval (1998)). Recent empirical work by Desai, Foley, and Hines (2003) confirms this view but also shows that, despite the tax advantage, the use of internal debt has its limits, i.e. internal debt is usually combined with external debt and equity. One explanation for the fact that multinational firms cannot use internal debt without limits is that tax authorities are aware of the profit shifting opportunities offered by internal debt. Therefore, many governments have introduced anti tax avoidance laws in order to limit profit shifting. ${ }^{11}$ For instance, German corporate tax law includes a rule ( $\S 8 \mathrm{a}, \mathrm{KStG}$ ) whereby interest deductions for internal debt will only be granted if the credit would also have been granted by third parties. Similar rules exist in the UK (see Rowland (1995)) and in the US (see Levin (1994)). These rules leave some discretion to tax authorities and courts in dealing with internal debt. It is plausible to assume that the chances of firms to avoid the application of anti tax avoidance legislation will be better, the smaller the share of internal debt in overall assets. Also, the amount of advice by tax consultants required to achieve a deduction for interest on internal debt is likely to be convex in the level of internal debt. Our model captures this by assuming that $\Psi(\alpha, \sigma)$ is convex in $\sigma$.

The firm's second period profits are thus given by

$$
\begin{aligned}
\pi_{2}= & \sum_{i=1}^{n}\left[\left(1-\tau_{i}\right)\left(F\left(K_{i}, L_{i}\right)-w_{i} L_{i}-\Psi\left(\alpha_{i}, \sigma_{i}\right) r K_{i}\right)+K_{i}\right] \\
& -(1+r) \sum_{i=1}^{n} \alpha_{i} K_{i}+r \sum_{i=1}^{n}\left(\alpha_{i}+\sigma_{i}\right) K_{i} \tau_{i}+\sum_{i=1}^{n} \varepsilon_{i} K_{i} \tau_{i}
\end{aligned}
$$

where $\varepsilon_{i}$ is a parameter describing the depreciation allowances of the tax system in country $j$. True economic depreciation implies $\varepsilon_{i}=0$. Accordingly, $\varepsilon_{i}<0$ implies less than economic depreciation whereas $\varepsilon_{i}>0$ would characterize a tax system with accelerated depreciation. The lowest possible value for $\varepsilon_{i}$ is $\varepsilon_{i}=-1$, which would describe the extreme case where investment goods cannot be depreciated for tax purposes at all. The first term on the right hand side of (7) represents output minus wage payments minus financing costs and the tax free capital repayment $K_{i}$. The second term is the payment of credit plus interest on external debt. The third term represents the interest deductions on overall debt and the fourth term represents the value of depreciation allowances as far as they deviate from economic depreciation.

The firm maximizes the present value of the dividends paid to the owners. Since there may be owners in different countries who may face different capital income tax rates, the question arises how the firm determines the opportunity cost of investment and, hence, the relevant discount rates. We simply assume that the firm uses a weighted average of the different discount rates ${ }^{12}$, so that the objective function of the firm is

$$
\Pi=\pi_{1}+\frac{\pi_{2}}{\sum_{i=1}^{n} \beta_{i}\left(1+r\left(1-t_{i}\right)\right)}
$$

where $\beta_{j}, j=1 \ldots n$, is the ownership share of the representative household residing in country $j$. Using $\pi_{1}=R-\sum_{i=1}^{n}\left(1-\alpha_{i}\right) K_{i}$, substituting (7) into (8) and maximizing (8) over $L_{j}$ and

\footnotetext{
${ }^{11}$ For an analysis of the impact of anti tax avoidance measures on the cost of capital of for eign subsidiaries see Weichenrieder (1996).

${ }^{12}$ To the extent that the following analysis applies to the case with owners residing in different countries, we will concentrate on symmetric equilibria, so that owner heterogeneity does not play an important role.
} 
$K_{j}$ yields

$$
\begin{aligned}
& \frac{\partial F\left(K_{j}, L_{j}\right)}{\partial K_{j}}=\phi_{j} \\
& \frac{\partial F\left(K_{j}, L_{j}\right)}{\partial L_{j}}=w_{j}
\end{aligned}
$$

where

$$
\phi_{j} \equiv\left[r \Psi\left(\alpha_{j}, \sigma_{j}\right)+\frac{r\left(1-\left(\alpha_{j}+\sigma_{j}\right) \tau_{j}-\left(1-\alpha_{j}\right) \sum_{i=1}^{n} \beta_{i} t_{i}\right)-\varepsilon_{j} \tau_{j}}{1-\tau_{j}}\right]
$$

is the cost of capital for investment in country $j$. Maximization of (8) over $\alpha_{j}$ and $\sigma_{j}$ yields:

$$
\Psi_{\alpha}\left(\alpha_{j}, \sigma_{j}\right)=\frac{\tau_{j}-\sum_{i=1}^{n} \beta_{i} t_{i}}{1-\tau_{j}}
$$

and

$$
\Psi_{\sigma}\left(\alpha_{j}, \sigma_{j}\right)=\frac{\tau_{j}}{1-\tau_{j}}
$$

While (9) and (10) are standard marginal productivity conditions, (11) and (12) describe the optimal financial structure of the firm. In the absence of taxes, the firm minimizes the nontax cost of financing by setting $\alpha=\alpha^{*}$ and $\sigma=0$. If taxes exist but $\tau_{j}=\sum_{i=1}^{n} \beta_{i} t_{i}$, the tax system is neutral with respect to the firm's choice of external debt because the tax advantage of debt caused by the deductibility of interest at the corporate level is neutralized by the taxation of interest income at the personal level. In contrast, if $\tau_{j}<\sum_{i=1}^{n} \beta_{i} t_{i}$, the tax system distorts the financial structure in favour of equity and vice versa. Of course, as (12) shows, any positive corporate income tax will give rise to income shifting via internal debt $(\sigma>0)$.

Given the assumption that the production function is linear-homogenous in $K$ and $L$, which implies $F\left(K_{i}, L_{i}\right)-w_{i} L_{i}=\frac{\partial F\left(K_{i}, L_{j}\right)}{\partial K_{j}} K_{j}=\phi_{j} K_{j}$, equations (9) to (12) determine the functions $\alpha_{j}=\alpha_{j}\left(\tau_{j}, t\right), w_{j}=w_{j}\left(\phi_{j}\right)$ and $K_{j}=K_{j}\left(\phi_{j}, L\right)$. In equilibrium, employment is effectively determined by the labour supply function, i.e. $L_{j}=L_{j}^{s}\left(r^{n}, w^{n}, P\right)$. The constant returns to scale assumption implies that there are no (supernormal) profits. Using (9) to (12), it is straightforward to show that, in equilibrium, $\Pi=\pi_{1}+\frac{\pi_{2}}{\sum_{i=1}^{n} \beta_{i}\left(1+r\left(1-t_{i}\right)\right)}=R$, i.e. the present value of the firm's stream of dividends is equal to the firm's endowment with retained earnings.

\subsection{The government}

The government has to finance a given level of public expenditures $(G)$ using the wage tax, the tax on personal savings and the corporate income tax. ${ }^{13}$

The government budget constraint is

$$
\begin{aligned}
G_{j}= & \left(w_{j}-w_{j}^{n}\right) L_{j}+r t_{j} S_{j}+\tau_{j}\left[F\left(K_{j}, L_{j}\right)-w_{j} L_{j}-\Psi\left(\alpha_{j}, \sigma_{j}\right) r K_{j}\right. \\
& \left.-r\left(\alpha_{j}+\sigma_{j}\right) K_{j}-\varepsilon_{j} K_{j}\right]
\end{aligned}
$$

The first and second terms on the right hand side of (13) represent the revenue from the labour and savings income tax. The third term represents revenue from corporate income taxation.

\footnotetext{
${ }^{13}$ We abstract from dividend taxes because, in line with the "new view" of dividend taxation, dividend taxes would be neutral in our model. Adding dividend taxes would imply that the government will receive some revenue from a non-distortionary tax. But the main results of our analysis would not change.
} 
Using $S_{j}=S_{j}^{*}+D_{j 1}=S_{j}^{*}+\beta_{j}\left(R-\sum_{i=1}^{n}\left(1-\alpha_{i}\right) K_{i}\right)$ and $F\left(K_{i}, L_{i}\right)-w_{i} L_{i}=\phi_{j} K_{j}$, the budget constraint can be written as

$$
\begin{aligned}
G_{j}= & \left(w_{j}-w_{j}^{n}\right) L_{j}+r t_{j}\left(S_{j}^{*}+\beta_{j} R\right)+\tau_{j} K_{j}\left[\phi_{j}-\Psi\left(\alpha_{j}, \sigma_{j}\right) r-r\left(\alpha_{j}+\sigma_{j}\right)-\varepsilon_{j}\right] \\
& -r \beta_{j} t_{j} \sum_{i=1}^{n}\left(1-\alpha_{i}\right) K_{i} .
\end{aligned}
$$

\section{The optimal tax policy under tax competition}

In this section, we derive the optimal tax policy in our model. The government of each country maximizes the utility of the representative citizen and takes the tax policy of all other countries as given. It is convenient to formulate the maximization problem of the government in the following way:

$$
\max _{w_{j}^{n}, t_{j}, \phi_{j}, \tau_{j}, \varepsilon_{j}} V\left(r^{n}, w^{n}, P\right)
$$

s.t.

$$
\begin{aligned}
& G_{j}=\left(w_{j}-w_{j}^{n}\right) L_{j}+r t_{j}\left(S_{j}^{*}+\beta_{j} R\right)+\tau_{j} K_{j}\left[\phi_{j}-\Psi\left(\alpha_{j}, \sigma_{j}\right) r-r\left(\alpha_{j}+\sigma_{j}\right)-\varepsilon_{j}\right] \\
&-r \beta_{j} t_{j} \sum_{i=1}^{n}\left(1-\alpha_{i}\right) K_{i} . \\
& \phi_{j} \equiv {\left[r \Psi\left(\alpha_{j}, \sigma_{j}\right)+\frac{r\left(1-\left(\alpha_{j}+\sigma_{j}\right) \tau_{j}-\left(1-\alpha_{j}\right) \sum_{i=1}^{n} \beta_{i} t_{i}\right)-\varepsilon_{j} \tau_{j}}{1-\tau_{j}}\right] } \\
& \varepsilon_{j} \geq-1
\end{aligned}
$$

The formal derivation of the optimal tax policy is given in the appendix. In the text, we only present the results and discuss their economic implications. Our main interest is to analyze the consequences of foreign firm ownership and income shifting through internal debt for the optimal tax policy of the individual countries. Moreover, we ask whether there is scope for policy coordination among the member states of the union. We therefore proceed in four steps. We start by considering the optimal tax policy of an individual country where the domestic household fully owns the multinational firm and no internal debt exists. We then consider the case where firm ownership is symmetric, i.e. the representative household in each country owns a share $1 / n$ in the firm's equity. The third step is to allow for income shifting. Finally, we will analyze the potential for welfare enhancing policy coordination.

\subsection{No internal debt, no foreign firm ownership}

This case refers to a situation where the ownership of the multinational firm is concentrated in one country. We refer to this country as country 1 . The possibility of income shifting through debt is ruled out. The optimal tax policy of country 1 may be characterized by the following

Proposition 1 If income shifting through internal debt is ruled out $(\sigma=0)$ and if the multinational firm is fully owned by the domestic household $\left(\beta_{1}=1\right)$, the optimal tax policy in country 1 is given by $\tau_{1}=t_{1}, \varepsilon_{1}=0$,

$$
\frac{\gamma-\lambda}{\gamma} L_{1}-\left(r t_{1} \frac{\partial S^{*}}{\partial w_{1}^{n}}+\left(w_{1}-w_{1}^{n}\right) \frac{\partial L_{1}}{\partial w_{1}^{n}}\right)=0
$$


and

$$
\begin{gathered}
\frac{\gamma-\lambda}{\gamma}\left[S^{*}+R\right]-\left(r t_{1} \frac{\partial S^{*}}{\partial r^{n}}+\left(w_{1}-w_{1}^{n}\right) \frac{\partial L}{\partial r^{n}}\right)-\sum_{i=2}^{n}\left(1-\alpha_{i}\right) K_{i} \\
+t_{1} \sum_{i=2}^{n} \frac{\partial \alpha_{i}}{\partial t_{1}} K_{i}=0
\end{gathered}
$$

Proof: See the appendix.

The interpretation of the results in proposition 1 is as follows. Firstly, the corporate income tax rate is equal to the tax rate on income from personal savings. This reflects that the corporate income tax in our model has the function to prevent that taxpayers avoid the savings tax by deferring the distribution of profits. They can defer profit distributions either by increasing the share of equity financing or by increasing the level of the firm's real investment. The optimal tax policy sets $\tau_{1}=t_{1}$ in order to avoid distortions of financial structure or real investment.

The level of the savings tax and the labour income tax are determined by the usual tradeoff between the necessity to raise tax revenue and the distortions of savings and labour supply decisions which characterizes a second best optimal tax system. These considerations are reflected by the first two terms on the left hand side of equations (15) and (16). The third term on the left hand side of (16) reflects that part of the household's savings effectively consist of retained earnings which the firm uses to finance real investment in other countries. While savings in the form of domestic, equity financed real investment are taxed via the corporate income tax, savings in the form of equity financed real investment abroad escape domestic taxation. There is nothing the government can do about this in our model. The fourth term on the left hand side of (16) reflects that an increase in the domestic savings tax will induce the multinational firm to increase the amount of equity financed investment abroad, so that the domestic tax base is reduced further. The result that the government sets $\varepsilon=0$, together with $\tau=t$, implies that production efficiency is preserved, i.e. the cost of capital is the same as in the absence of taxes: $\phi_{1}=r(1+\Psi)$

\subsection{The impact of foreign firm ownership}

Assume now that the ownership of the firm is symmetrically distributed among all countries, so that the representative household in country $j$ only owns a share $\beta_{j}=1 / n$ of the firm's equity. As in the preceding section, we assume that income shifting through internal debt is ruled out. The optimal levels of the tax on labour income and the personal tax on savings are again determined by standard optimal tax considerations as described above. We therefore concentrate on the corporate tax system. Here we may state

Proposition 2 If firm ownership is distributed symmetrically among all countries $\left(\beta_{j}=1 / n, j=1 . . n\right)$ and income shifting is ruled out, the optimal tax policy of country $j$ implies $\tau_{j}<t_{j}$ and $\varepsilon_{j}=0$. Real investment is subsidized: $\phi_{j}<r(1+\Psi)$.

Proof: See the appendix.

Interestingly, while the government sets $\tau_{j}=t_{j}$ if the household entirely owns the firms operating within the country, we now have $\tau_{j}<t_{j}$, which implies that foreign firm ownership 
reduces the corporate tax rate and leads to a situation where investment is effectively subsidized. This happens for the following reason. The corporate income tax has the function to prevent that households avoid personal income taxes by increasing equity financing and overinvesting in the domestic corporate sector. The government designs the corporate income tax system so that the effect of a marginal change in domestic investment $K_{j}$ on the government budget constraint is zero. Given the financial structure $\alpha_{j}$, an increase in domestic investment by one Euro reduces dividend distributions to and, hence, private savings of domestic households in period 1 by $\beta_{j}\left(1-\alpha_{j}\right)$ Euros. As a result, the revenue from the savings tax declines by $r t \beta_{j}\left(1-\alpha_{j}\right)$. The optimal corporate tax neutralizes this revenue loss. But if the domestic ownership share $\beta_{j}$ is small, the optimal corporate income tax declines. In our model, if $n$ approaches infinity, i.e. the ownership share of the domestic household in the firms operating domestically becomes negligible, the optimal corporate tax rate approaches zero.

The result that the corporate tax rate declines as foreign ownership of domestic firms increases is diametrically opposed to the findings in Huizinga and Nielsen (1997), where foreign firm ownership leads to higher corporate tax rates. The reason for this difference is that the corporate tax in Huizinga and Nielsen (1997) has a different economic function. In their model, firms earn supernormal profits which cannot be taxed directly. Therefore, a corporate tax which distorts investment is used as an indirect way of taxing these profits. If foreign firm ownership increases, an increasing share of profits generated domestically accrues to foreigners, so that the burden of domestic corporate taxes also partly falls on foreigners. Consequently, more foreign firm ownership increases the optimal corporate tax rate. In our model, this type of tax exporting motive does not exist.

\subsection{Income Shifting without foreign firm ownership}

We now consider the case where firms may use internal debt to avoid domestic corporate income taxes. In order to be able to focus on the role of income shifting, we abstract from foreign firm ownership by considering the case where the household of country 1 owns $100 \%$ of the multinational firm's equity. As in the preceding section, we focus on the optimal corporate tax policy which is summarized by

Proposition 3 If firms may use internal debt for income shifting and if firm ownership is concentrated in country $1\left(\beta_{1}=1\right)$, the optimal tax system implies $\tau_{1}<t_{1}$ and $\varepsilon_{1}<0$. Production efficiency is preserved: $\phi_{1}=r\left(1+\Psi_{1}\right)$.

Proof: See the appendix.

It turns out that the existence of income shifting induces governments to reduce the corporate tax rate and at the same time to broaden the tax base by curtailing depreciation allowances. This may be explained as follows. The government wants to reduce the corporate tax rate in order to limit the incentives to shift income to tax havens via internal debt. But reducing the corporate tax rate below the income tax rate distorts the choice between equity and external debt in favour of equity. The optimal corporate tax rate reflects the trade-off between the aims of reducing income shifting and the desire to limit the distortion of the financial structure of firms in favour of equity. ${ }^{14}$ Next to the effect on the financial structure

\footnotetext{
${ }^{14}$ The existence of external debt thus acts as a break on corporate tax rate reductions. A referee raised the question of how the results would change if we assumed that firms did not use external debt at all. In this case, it can be shown that the government would set $\tau<t$ and $\varepsilon=-1$, i.e. the pressure to broaden corporate tax bases and to reduce tax rates would increase. The proof for this result is available from the authors on request.
} 
of the firm, the reduction of the corporate tax rate below the income tax rate $t$ also implies that the domestic tax system subsidizes domestic real investment. Since such a subsidy is not desirable, the government reduces depreciation allowances $\left(\varepsilon_{j}<0\right)$ in order to restore production efficiency.

How is the result in proposition 3 related to explanations for tax rate cut cum base broadening policies existing in the literature? Haufler and Schjelderup (2000) consider a model where firms make pure profits and may use transfer pricing to shift these profits to tax haven countries. Without profit shifting via transfer prices, national governments would levy cash flow taxes which allow to tax pure profits at $100 \%$ without distorting the marginal investment decision. If however firms can avoid a confiscatory taxation of their profits by shifting profits to other countries, countries will reduce their tax rates below $100 \%$ in order to limit the incentives for income shifting. But given that pure profits are now partly untaxed, it is no longer optimal to preserve production efficiency. Instead, countries broaden their tax bases and deviate from production efficiency. The difference to our results is that, in our model, there are no supernormal profits and, more importantly, the broadening of the tax base aims at restoring production efficiency rather than deviating from it.

Bond (2000) explains the tax rate cut cum base broadening policy as reflecting the view that multinational firms make discrete investment decisions which are guided by average rather than marginal tax rates. Osmundsen, Hagen, and Schjelderup (1998) consider a world where firms differ with respect to their mobility and corporate tax policy is plagued by problems of asymmetric information. In this framework, a tax rate cut cum base broadening policy is optimal because it improves incentives for relatively immobile firms to reveal their true type instead of mimicking mobile firms.

\subsection{Income shifting and foreign firm ownership}

The case analyzed in the preceding section refers to a world where firm ownership is completely concentrated in one country. Given the setup of our model, this would imply that there are $n-1$ countries where the domestic household owns no equity of the multinational firm, so that these countries do not levy corporate income taxes. Such an equilibrium is not realistic. In this section, we therefore consider the case where income shifting exists but countries are symmetric, i.e. the representative household in each country owns a share $\beta_{j}=1 / n$ of the firm's equity. The optimal tax policy is now as follows:

Proposition 4 If firms may use internal debt for income shifting and if firm ownership is distributed symmetrically among all countries $\left(\beta_{j}=1 / n, j=1 . . n\right)$, the optimal tax policy of country $j$ implies $\tau_{j}<t_{j}$ and $\varepsilon_{j}<0$. Real investment is subsidized: $\phi_{j}<r(1+\Psi)$.

Proof: See the appendix.

Proposition 4 shows that, in the presence of both income shifting and foreign firm ownership, the effects discussed in the preceding sections are combined. Propositions 3 and 4 have in common that the optimal tax policy implies $\tau_{j}<t_{j}$ and $\varepsilon_{j}<0$. This means that a tax rate cut cum base broadening policy is optimal for any ownership structure (apart from the extreme case of $\beta_{j}=0$, where country $j$ does not levy corporate taxes). It is sufficient that income shifting through internal debt occurs. The explanation for this result is that governments reduce their corporate tax rates in order to limit the use of internal debt. But this has the undesirable consequence that domestic investment is subsidized, at the margin. The broadening of the tax base corrects this distortion. The result in proposition 4 that real 
investment is subsidized (whereas this is not the case in proposition 3) is a consequence of foreign firm ownership.

\section{Policy coordination}

It is natural to ask whether there is room for welfare enhancing policy coordination among the $n$ countries of the union. It is well known from the literature on tax coordination that a case for tax coordination can be made on the basis that the elasticity of capital supply for the union as a whole may differ from the elasticity of capital supply faced by individual countries. By assuming that the effect of the union on the world interest rate is negligible, this class of arguments in favour of tax coordination is ruled out in our model. Moreover, it is well known that asymmetries between countries considerably complicates the analysis of tax coordination because some countries may gain at the expense of other countries. We therefore focus on the question of tax coordination among symmetric countries. Here, we may state:

Proposition 5 If firms may use internal debt for income shifting and if firm ownership is distributed symmetrically among all countries $\left(\beta_{j}=1 / n, j=1 . . n\right)$, a coordinated increase of the corporate tax rate, departing from the equilibrium without coordination and holding constant the depreciation parameter $\varepsilon$, increases welfare.

Proof: See the appendix.

The reason for the positive welfare effect of an increase in the corporate tax rate is best understood by considering the fiscal externalities associated with a change in the tax rate. A higher corporate tax rate in country $j$ reduces the share of equity in the financing of real investment in this country, i.e. $\alpha_{j}$ increases. Moreover, an increase in $\tau_{j}$ raises the cost of capital in country $j$ and reduces the level of real investment $K_{j}$. Both effects raise the dividend distributed in period 1. Since firm ownership is symmetrically distributed over all countries of the union, the higher dividend in period 1 increases private savings and, hence, revenue from the savings tax in all countries. This effect on savings tax revenue in other countries constitutes a positive fiscal externality.

One may note that this reason for the positive welfare effect of a coordinated increase in the corporate tax rate differs from the standard argument in favour of corporate tax coordination, which is based on the idea that higher taxes in one country increase real investment in other countries. This type of fiscal externality is absent from our model because the union is assumed to have no impact on the interest rate in the world capital market. ${ }^{15}$

For similar reasons, our model allows to make a case for tax base coordination:

Proposition 6 If firms may use internal debt for income shifting and if firm ownership is distributed symmetrically among all countries $\left(\beta_{j}=1 / n, j=1 . . n\right)$, a coordinated reduction of the depreciation parameter $\varepsilon_{j}$, departing from the equilibrium without coordination and holding constant the corporate tax rate, increases welfare.

Proof: See the appendix.

The reduction in the depreciation parameter implies a further broadening of the tax base (note that the reform already departs from an equilibrium with $\varepsilon_{j}<0$ ). The reason for the

\footnotetext{
${ }^{15}$ Tax coordination among countries of a union which has some market power in the international capital market is studied e.g. by Konrad and Schjelderup (1999).
} 
positive welfare effect of a coordinated broadening of the tax base is again that changes in the depreciation parameter in one country give rise to a fiscal externality: under tax competition, the individual countries do not take into account that, by broadening the tax base, real investment of the multinational firm declines and more funds are distributed in period 1 , so that savings tax revenue in all countries increases.

\section{Conclusions}

In this paper, we have analyzed the implications of international income shifting and foreign firm ownership for corporate tax policy. Our analysis has shown that foreign firm ownership does not necessarily act as a break on tax rate reductions. Moreover, tax rate cut cum base broadening policies may be seen as a reaction of national tax policies to income shifting through internal debt. This result is similar to the findings in Haufler and Schjelderup (2000), but the reason for the broadening of the tax base and the implications for production efficiency are different. Finally, we have shown that there is a potential for welfare enhancing coordination of tax rates and tax bases in our model.

There are several limitations of our analysis which should be taken into account. Firstly, our analysis is based on the assumption that residence based taxation of personal savings is possible. It is well known that taxpayers may evade these taxes relatively easily by holding bank accounts in other countries. But as long as interest income can at least partly be taxed on a residence basis, our findings should continue to hold. Secondly, we assume that foreign firm ownership is given and ask how the optimal tax policy reacts to this. This neglects that the structure of firm ownership itself will be influenced by taxes. Clearly, investigating this is beyond the scope of this paper. ${ }^{16}$ Another, more fundamental issue raised by our analysis is whether countries should simply abolish interest deductions in order to avoid income shifting through debt. In our model, this would give rise to a severe distortion of the financial structure of firms in favour of equity financing, so that zero interest deductions are unlikely to be optimal. But it is not clear that this is a sufficient reason to maintain the full deductibility of interest. We intend to investigate this issue in future research.

\section{A Appendix}

In this appendix, we give the proofs of propositions 1-6. We start by deriving the firstorder conditions (f.o.c.) for the optimal tax policy. These will be used in the proofs of all propositions. The Lagrangean for the government's problem is

$$
\begin{gathered}
\Gamma\left(w_{j}^{n}, t_{j}, \phi_{j}, \tau_{j}, \varepsilon_{j}\right)=V\left(r^{n}, w^{n}, P\right)+\gamma\left\{\left(w_{j}-w_{j}^{n}\right) L_{j}+r t_{j}\left(S_{j}^{*}+\beta_{j} R\right)\right. \\
\left.+\tau_{j} K_{j}\left[\phi_{j}-\Psi\left(\alpha_{i}, \sigma_{i}\right) r-r\left(\alpha_{j}+\sigma_{j}\right)-\varepsilon_{j}\right]-r \beta_{j} t_{j} \sum_{i=1}^{n}\left(1-\alpha_{i}\right) K_{i}\right\} \\
+\eta\left[\phi_{j}-\left(r \Psi\left(\alpha_{j}, \sigma_{j}\right)+\frac{r\left(1-\left(\alpha_{j}+\sigma_{j}\right) \tau_{j}-\left(1-\alpha_{j}\right) \sum_{i=1}^{n} \beta_{i} t_{i}\right)-\varepsilon_{j} \tau_{j}}{1-\tau_{j}}\right)\right] \\
+\vartheta(\varepsilon+1)
\end{gathered}
$$

\footnotetext{
${ }^{16}$ For an analysis of the impact of economic integration on tax policy in a model with endogenous foreign firm ownership see Fuest (2003).
} 
The first-order-conditions are

$$
\begin{aligned}
& \frac{\partial \Gamma}{\partial w_{j}^{n}}=(\lambda-\gamma) L+\gamma\left[r t_{j} \frac{\partial S^{*}}{\partial w_{j}^{n}}+\left(w_{1}-w_{1}^{n}\right) \frac{\partial L_{j}}{\partial w_{j}^{n}}\right. \\
& \left.+\frac{\partial K_{j}}{\partial L_{j}} \frac{\partial L_{j}}{\partial w_{j}^{n}}\left(\tau_{j}\left[\phi_{j}-\Psi\left(\alpha_{i}, \sigma_{i}\right) r-r\left(\alpha_{j}+\sigma_{j}\right)-\varepsilon_{j}\right]-r \beta_{j} t_{j}\left(1-\alpha_{j}\right)\right)\right]=0 \\
& \frac{\partial \Gamma}{\partial t_{j}}=(\gamma-\lambda) r\left[S^{*}+\beta_{j} R\right]+\gamma\left[r t_{1} \frac{\partial S^{*}}{\partial r^{n}}(-r)+\left(w_{1}-w_{1}^{n}\right) \frac{\partial L}{\partial r^{n}}(-r)\right. \\
& +\frac{\partial K_{j}}{\partial L_{j}} \frac{\partial L}{\partial r^{n}}(-r)\left\{\tau_{j}\left[\phi_{j}-\Psi\left(\alpha_{i}, \sigma_{i}\right) r-r\left(\alpha_{j}+\sigma_{j}\right)-\varepsilon_{j}\right]-r \beta_{j} t_{j}\left(1-\alpha_{j}\right)\right\} \\
& +r\left[\beta_{j} t_{j} K_{j}-\tau_{j} K_{j}\left[\left(\Psi_{\alpha}+1\right]\right] \frac{\partial \alpha_{j}}{\partial t_{j}}-r \beta_{j} \sum_{i=1}^{n}\left(1-\alpha_{i}\right) K_{i}+r \beta_{j} t_{j} \sum_{i \neq j} \frac{\partial \alpha_{i}}{\partial t_{j}} K_{i}\right] \\
& +\eta \frac{\left(1-\alpha_{j}\right) \beta_{j} r}{\left(1-\tau_{j}\right)}=0 \\
& \frac{\partial \Gamma}{\partial \phi_{j}}=-\gamma K_{j}\left(1-\tau_{j}\right)+\eta \\
& +\gamma\left[\frac{\partial K_{j}}{\partial \phi_{j}}\left(\tau_{j}\left(\phi_{j}-r \Psi\left(\alpha_{i}, \sigma_{i}\right)-\left(\alpha_{i}+\sigma_{i}\right) r-\varepsilon_{j}\right)-r t_{j} \beta_{j}\left(1-\alpha_{j}\right)\right)\right]=0 \\
& \frac{\partial \Gamma}{\partial \varepsilon_{j}}=-\gamma \tau_{j} K_{j}+\eta \frac{\tau_{j}}{\left(1-\tau_{j}\right)}+\vartheta=0 \\
& \frac{\partial \Gamma}{\partial \tau_{j}}=\left(\gamma K_{j}-\frac{\eta}{\left(1-\tau_{j}\right)}\right)\left(\phi_{j}-r \Psi\left(\alpha_{i}, \sigma_{i}\right)-\left(\alpha_{i}+\sigma_{i}\right) r-\varepsilon_{j}\right) \\
& +\gamma\left(\beta_{j} t_{j}-\tau_{j}\left(\Psi_{\alpha}+1\right)\right) r K_{j} \frac{\partial \alpha_{j}}{\partial \tau_{j}}-\gamma\left(\Psi_{\sigma}+1\right) r K_{j} \tau_{j} \frac{\partial \sigma_{j}}{\partial \tau_{j}}=0
\end{aligned}
$$

We focus on the case where the constraint $\varepsilon \geq-1$ is not binding, so that $\vartheta=0$. Given this, equations (A.3) to (A.5) can be transformed into:

$$
\begin{gathered}
\frac{\tau_{j}}{\left(1-\tau_{j}\right)}\left\{r\left(1-\left(\alpha_{j}+\sigma_{j}\right)-(1-\alpha) \sum_{i=1}^{n} \beta_{i} t_{i}\right)-\varepsilon_{j}\right\}-r \beta_{j} t_{j}\left(1-\alpha_{j}\right)=0 \\
\frac{\partial \alpha_{j}}{\partial \tau_{j}}\left\{\tau_{j}\left(1-\sum_{i \neq j} \beta_{i} t_{i}\right)-\beta_{j} t_{j}\right\}+\frac{\partial \sigma_{j}}{\partial \tau_{j}} \tau_{j}=0
\end{gathered}
$$

Proof of proposition 1. If $\sigma_{j}=0, \frac{\partial \sigma_{j}}{\partial \tau_{j}}=0, \beta_{j}=1, j=1$, and using (A.4) in (A.2), (A.1) and (A.2) yield (15) and (16) in proposition 1. (A.7) and (A.6) collapse to $\tau_{j}=t_{j}$ and $\varepsilon_{j}=0$. Q.E.D.

Proof of proposition 2. If $\sigma_{j}=0, \frac{\partial \sigma_{i}}{\partial \tau_{j}}=0, \beta_{j}=1 / n, j=1 \ldots n,($ A.7) yields

$$
\tau_{j}\left(1-\frac{(n-1)}{n} t_{j}\right)-\frac{t_{j}}{n}=0
$$


which can be rearranged to

$$
\tau_{j}=\frac{t_{j}}{1+(n-1)\left(1-t_{j}\right)}<t_{j}
$$

Using $\sigma_{j}=0, \frac{\partial \sigma_{j}}{\partial \tau_{j}}=0, \beta_{j}=1 / n, j=1 \ldots n$ in (A.6) yields $\varepsilon_{j}=0$. Using $\varepsilon_{j}=0$ and $\tau_{j}=\frac{t_{i}}{1+(n-1)\left(1-t_{j}\right)}$ in $(9)$ shows that

$$
\phi_{j}=r\left(\Psi_{j}+1-\left(1-\alpha_{j}\right) t_{j} \frac{(n-1)}{n}\right)<r\left(\Psi_{j}+1\right)
$$

Q.E.D.

Proof of proposition 3 . If $\beta_{j}=1, j=1$, it follows from (A.7) that

$$
\tau_{j}-t_{j}=-\tau_{j} \frac{\frac{\partial \sigma_{i}}{\partial t_{j}}}{\frac{\partial \alpha_{i}}{\partial t_{j}}}<0
$$

$>$ From (A.6), we get

$$
\tau_{j}-t_{j}=\tau_{j} \frac{\sigma_{j}+\frac{\varepsilon_{i}}{r}}{\left(1-\alpha_{j}\right)}
$$

Since $\sigma_{j}>0$ it follows that $\varepsilon_{j}<0$. Substituting (A.8) into (9) yields

$$
\phi_{j}=r\left(\Psi_{j}+1\right)
$$

Q.E.D.

Proof of proposition 4. If $\beta_{j}=1 / n, j=1 . . n,($ A.7) yields

$$
\left(\tau_{j}\left(1-\frac{(n-1)}{n} t_{j}\right)-\frac{t_{j}}{n}\right) \frac{\partial \alpha_{j}}{\partial t_{j}}+\tau_{j} \frac{\partial \sigma_{j}}{\partial t_{j}}=0
$$

which can be rearranged to

$$
\tau_{j}\left(1-t_{j}\right)-\frac{t_{j}}{n}\left(1-\tau_{j}\right)=-\tau_{j} \frac{\frac{\partial \sigma_{j}}{\partial t_{j}}}{\frac{\partial \alpha_{j}}{\partial t_{j}}}
$$

This implies

$$
\tau_{j}<\frac{t_{j}}{1+(n-1)\left(1-t_{j}\right)}
$$

It follows that $\tau_{j}<t_{j}$. Using $\beta_{j}=1 / n, j=1 . . n$ in (A.6) yields

$$
\tau_{j}\left(1-t_{j}\right)-\frac{t_{j}}{n}\left(1-\tau_{j}\right)=\tau_{j} \frac{\sigma_{j}+\frac{\varepsilon_{j}}{r}}{\left(1-\alpha_{j}\right)}
$$

Since $\sigma_{j}>0$ and given that the left hand side of (A.9) is negative, it follows that $\varepsilon_{j}<0$. Using these results in (9) yields

$$
\phi_{j}=r\left(\Psi_{j}+1-\left(1-\alpha_{j}\right) t_{j} \frac{(n-1)}{n}\right)<r\left(\Psi_{j}+1\right)
$$

Q.E.D. 
Proof of proposition 5. A coordinated change in $\tau_{j}, j=1 \ldots . n$ affects welfare directly and via the induced change in the cost of capital. The change in the cost of capital is given by

$$
\frac{\partial \phi_{j}}{\partial \tau_{j}}=\frac{\phi_{j}-r \Psi_{j}}{\left(1-\tau_{j}\right)^{2}}-\frac{r\left(\alpha_{j}+\sigma_{j}\right)+\varepsilon_{j}}{\left(1-\tau_{j}\right)}
$$

Using the results of proposition 4 , this can be transformed into

$$
\frac{\partial \phi_{j}}{\partial \tau_{j}}=r\left(1-\alpha_{j}\right)\left[1-t \frac{(n-1)}{n}\right]>0
$$

The effect on the welfare of country $j$ is given by

$$
d \Gamma_{j}=\frac{\partial \Gamma_{j}}{\partial \tau_{j}}+\sum_{i=1}^{n} \frac{\partial \Gamma_{j}}{\partial \phi_{i}} \frac{\partial \phi_{i}}{\partial \tau_{i}}
$$

Given that the f.o.c. for the optimal policy under tax competition imply $\frac{\partial \Gamma_{j}}{\partial \tau_{j}}=0$ and $\frac{\partial \Gamma_{j}}{\partial \phi_{j}}=0$, the welfare effect is equal to

$$
d \Gamma_{j}=\sum_{i \neq j}^{n} \frac{\partial \Gamma_{j}}{\partial \phi_{i}} \frac{\partial \phi_{i}}{\partial \tau_{i}}=-\gamma r \frac{t_{j}}{n} \sum_{i \neq j}^{n}\left[\left(1-\alpha_{i}\right) \frac{\partial K_{i}}{\partial \phi_{i}} \frac{\partial \phi_{i}}{\partial \tau_{i}}-\frac{\partial \alpha_{i}}{\partial \tau_{i}} K_{i}\right]>0
$$

Q.E.D.

Proof of proposition 6. A coordinated change in $\varepsilon_{j}, j=1 \ldots . n$ affects welfare directly and via the induced change in the cost of capital. The change in the cost of capital is given by

$$
\frac{\partial \phi_{j}}{\partial \varepsilon_{j}}=-\frac{\tau_{j}}{\left(1-\tau_{j}\right)}<0
$$

The effect on the welfare of country $j$ is given by

$$
d \Gamma_{j}=\frac{\partial \Gamma_{j}}{\partial \varepsilon_{j}}+\sum_{i=1}^{n} \frac{\partial \Gamma_{j}}{\partial \phi_{i}} \frac{\partial \phi_{i}}{\partial \varepsilon_{i}}
$$

Given that the f.o.c. for the optimal policy under tax competition imply $\frac{\partial \Gamma_{i}}{\partial \varepsilon_{j}}=0$ and $\frac{\partial \Gamma_{i}}{\partial \phi_{j}}=0$, the welfare effect is equal to

$$
d \Gamma_{j}=\sum_{i \neq j}^{n} \frac{\partial \Gamma_{j}}{\partial \phi_{i}} \frac{\partial \phi_{i}}{\partial \varepsilon_{i}}=-\gamma r \frac{t_{j}}{n} \sum_{i \neq j}^{n}\left[\left(1-\alpha_{i}\right) \frac{\partial K_{i}}{\partial \phi_{i}} \frac{\partial \phi_{i}}{\partial \varepsilon_{i}}\right]<0
$$

which implies that a coordinated reduction in $\varepsilon$ increases welfare. Q.E.D.

\section{References}

Bond, R. S. (2000): "Levelling Up or Levelling Down? Some Reflections on the ACE and CBIT Proposals, and the Future of the Corporate Tax Base," in Taxing Capital Income in the European Union. Issues and Options for Reform, ed. by S. Cnossen, pp. 161-179. Oxford University Press. 
Chow dhry, B., And J. D. Coval (1998): "Internal Financing of Multinational Subsidiaries: Debt Vs. Equity," Journal of Corporate Finance, 4, 87-106.

Chowdhry, B., And V. Nanda (1994): "Financing of Multinational Subsidiaries: Parent Debt Vs. External Debt," Journal of Corporate Finance, 1, 259-281.

Desai, M. A., C. F. Foley, and J. R. Hines (2003): "A Multinational Perspective on Capital Structure Choice and Internal Capital Markets," NBER, (9715), NBER Working Paper Series.

Fuest, C. (2003): "Economic Integration and Tax Policy with Endogenous Foreign Firm Ownership," mimeo.

Fuest, C., And B. Huber (2002): "Why Capital Income Taxes Survive in Open Economies: The Role of Multinational Firms," International Tax and Public Finance, 9(5), 567-589.

Fuest, C., B. Huber, And J. Mintz (2003): "Tax Competition and Capital Mobility: A Survey," mimeo.

Gresik, T. A. (2001): "The Taxing Task of Taxing Multinationals," Journal of Economic Literature, XXXIX, 800-838.

HART, O. (1993): "Theories of Optimal Capital Structure: A Managerial Discretion Perspective," in The Deal Decade: What Takeovers and Leveraged Buyouts Mean for Corporate Governance, ed. by M. M. Blair, pp. 19-53. The Brookings Institution, Washington D. C.

Haufler, A., and G. Schjelderup (2000): "Corporate Tax Systems and Cross Country Profit Shifting," Oxford Economic Papers, 52, 306-325.

Huizing A, H., And S. B. Nielsen (1997): "Capital Income and Profit Taxation with Foreign Ownership of Firms," Journal of International Economics, 42, 149-165.

(2002): "The Coordination of Capital Income and Profit Taxation with CrossOwnership of Firms," Regional Science and Urban Economics, 32, 1-26.

Kind, H. J., K. H. Midelfart, and G. Schjelderup (2003): "Why Corporate Taxes May Rise: The Case of Economic Integration," mimeo.

Konrad, K. A., and G. Schjelderup (1999): "Fortress Building in Global Tax Competition," Journal of Urban Economics, 46(1), 156-167.

Levin, L. D. (1994): "A Short History of the Portfolio Interest Exemption and US Real Estate Investment by Non-Residents and Foreign Corporations: Too Much of a Good Thing," International Bulletin of Fiscal Documentation, pp. 624-629.

Malherbe, J. (2002): "Harmful Tax Competition and the Future of Financial Centres in the European Union," Intertax, 30(6-7), 219-224.

Mintz, J., And M. Smart (2001): "Income Shifting, Investment, and Tax Competition: Theory and Evidence from Provincial Taxation in Canada," CESifo Working Papers, (554).

(2002): "Tax-Exempt Investors and the Asset Allocation Puzzle," Journal of Public Economics, 83(2), 195-215. 
Olsen, T. E., And P. Osmundsen (2001): "Strategic Tax Competition; Implications of National Ownership," Journal of Public Economics, 81, 253-277.

Osmundsen, P., K. P. Hagen, and G. Schjelderup (1998): "Internationally Mobile Firms and Tax Policy," Journal of International Economics, 45, 97-113.

Richter, W. F., And D. Wellisch (1996): "The Presence of Local Public Goods and Factors in the Presence of Firm and Houshold Mobility," Journal of Public Economics, 60, 73-93.

Rowland, A. K. (1995): "Thin Capitalization in the United Kingdom," International Bulletin of Fiscal Documentation, pp. 554-558.

Weichenrieder, A. J. (1996): "Anti-Tax-Avoidance Provisions and the Size of Foreign Direct Investment," International Tax and Public Finance, 3, 67-81.

Wildasin, D. E., And J. D. Wilson (1998): "Risky Local Tax Bases: Risk-Pooling Vs. Rent Capture," Journal of Public Economics, 69, 229-247. 


\section{CESifo Working Paper Series}

(for full list see www.cesifo.de)

1031 Ivar Ekeland, James J. Heckman, and Lars Nesheim, Identifcation and Estimation of Hedonic Models, September 2003

1032 Kjetil Bjorvatn and Alexander W. Cappelen, Decentralization and the Fate of Minorities, September 2003

1033 Lars-Erik Borge and Jørn Rattsø, The Relationships Between Costs and User Charges: The Case of a Norwegian Utility Service, September 2003

1034 Maureen Were and Nancy N. Nafula, An Assessment of the Impact of HIV/AIDS on Economic Growth: The Case of Kenya, September 2003

1035 A. Lans Bovenberg, Tax Policy and Labor Market Performance, September 2003

1036 Peter Birch Sørensen, Neutral Taxation of Shareholder Income: A Norwegian Tax Reform Proposal, September 2003

1037 Roberta Dessi and Sheilagh Ogilvie, Social Capital and Collusion: The Case of Merchant Guilds, September 2003

1038 Alessandra Casarico and Carlo Devillanova, Capital-skill Complementarity and the Redistributive Effects of Social Security Reform, September 2003

1039 Assaf Razin and Efraim Sadka, Privatizing Social Security Under Balanced-Budget Constraints: A Political-Economy Approach, September 2003

1040 Michele Moretto, Paolo M. Panteghini, and Carlo Scarpa, Investment Size and Firm's Value under Profit Sharing Regulation, September 2003

1041 A. Lans Bovenberg and Peter Birch Sørensen, Improving the Equity-Efficiency Tradeoff: Mandatory Savings Accounts for Social Insurance, September 2003

1042 Bas van Aarle, Harry Garretsen, and Florence Huart, Transatlantic Monetary and Fiscal Policy Interaction, September 2003

1043 Jerome L. Stein, Stochastic Optimal Control Modeling of Debt Crises, September 2003

1044 Thomas Stratmann, Tainted Money? Contribution Limits and the Effectiveness of Campaign Spending, September 2003

1045 Marianna Grimaldi and Paul De Grauwe, Bubbling and Crashing Exchange Rates, September 2003 
1046 Assar Lindbeck and Dennis J. Snower, The Firm as a Pool of Factor Complementarities, September 2003

1047 Volker Grossmann, Firm Size and Diversification: Asymmetric Multiproduct Firms under Cournot Competition, September 2003

1048 Dan Anderberg, Insiders, Outsiders, and the Underground Economy, October 2003

1049 Jose Apesteguia, Steffen Huck and Jörg Oechssler, Imitation - Theory and Experimental Evidence, October 2003

1050 G. Abío, G. Mahieu and C. Patxot, On the Optimality of PAYG Pension Systems in an Endogenous Fertility Setting, October 2003

1051 Carlos Fonseca Marinheiro, Output Smoothing in EMU and OECD: Can We Forego Government Contribution? A Risk Sharing Approach, October 2003

1052 Olivier Bargain and Nicolas Moreau, Is the Collective Model of Labor Supply Useful for Tax Policy Analysis? A Simulation Exercise, October 2003

1053 Michael Artis, Is there a European Business Cycle?, October 2003

1054 Martin R. West and Ludger Wößmann, Which School Systems Sort Weaker Students into Smaller Classes? International Evidence, October 2003

1055 Annette Alstadsaeter, Income Tax, Consumption Value of Education, and the Choice of Educational Type, October 2003

1056 Ansgar Belke and Ralph Setzer, Exchange Rate Volatility and Employment Growth: Empirical Evidence from the CEE Economies, October 2003

1057 Carsten Hefeker, Structural Reforms and the Enlargement of Monetary Union, October 2003

1058 Henning Bohn and Charles Stuart, Voting and Nonlinear Taxes in a Stylized Representative Democracy, October 2003

1059 Philippe Choné, David le Blanc and Isabelle Robert-Bobée, Female Labor Supply and Child Care in France, October 2003

1060 V. Anton Muscatelli, Patrizio Tirelli and Carmine Trecroci, Fiscal and Monetary Policy Interactions: Empirical Evidence and Optimal Policy Using a Structural New Keynesian Model, October 2003

1061 Helmuth Cremer and Pierre Pestieau, Wealth Transfer Taxation: A Survey, October 2003

1062 Henning Bohn, Will Social Security and Medicare Remain Viable as the U.S. Population is Aging? An Update, October 2003

1063 James M. Malcomson, Health Service Gatekeepers, October 2003 
1064 Jakob von Weizsäcker, The Hayek Pension: An efficient minimum pension to complement the welfare state, October 2003

1065 Joerg Baten, Creating Firms for a New Century: Determinants of Firm Creation around 1900, October 2003

1066 Christian Keuschnigg, Public Policy and Venture Capital Backed Innovation, October 2003

1067 Thomas von Ungern-Sternberg, State Intervention on the Market for Natural Damage Insurance in Europe, October 2003

1068 Mark V. Pauly, Time, Risk, Precommitment, and Adverse Selection in Competitive Insurance Markets, October 2003

1069 Wolfgang Ochel, Decentralising Wage Bargaining in Germany - A Way to Increase Employment?, November 2003

1070 Jay Pil Choi, Patent Pools and Cross-Licensing in the Shadow of Patent Litigation, November 2003

1071 Martin Peitz and Patrick Waelbroeck, Piracy of Digital Products: A Critical Review of the Economics Literature, November 2003

1072 George Economides, Jim Malley, Apostolis Philippopoulos, and Ulrich Woitek, Electoral Uncertainty, Fiscal Policies \& Growth: Theory and Evidence from Germany, the UK and the US, November 2003

1073 Robert S. Chirinko and Julie Ann Elston, Finance, Control, and Profitability: The Influence of German Banks, November 2003

1074 Wolfgang Eggert and Martin Kolmar, The Taxation of Financial Capital under Asymmetric Information and the Tax-Competition Paradox, November 2003

1075 Amihai Glazer, Vesa Kanniainen, and Panu Poutvaara, Income Taxes, Property Values, and Migration, November 2003

1076 Jonas Agell, Why are Small Firms Different? Managers’ Views, November 2003

1077 Rafael Lalive, Social Interactions in Unemployment, November 2003

1078 Jean Pisani-Ferry, The Surprising French Employment Performance: What Lessons?, November 2003

1079 Josef Falkinger, Attention, Economies, November 2003

1080 Andreas Haufler and Michael Pflüger, Market Structure and the Taxation of International Trade, November 2003

1081 Jonas Agell and Helge Bennmarker, Endogenous Wage Rigidity, November 2003 
1082 Fwu-Ranq Chang, On the Elasticities of Harvesting Rules, November 2003

1083 Lars P. Feld and Gebhard Kirchgässner, The Role of Direct Democracy in the European Union, November 2003

1084 Helge Berger, Jakob de Haan and Robert Inklaar, Restructuring the ECB, November 2003

1085 Lorenzo Forni and Raffaela Giordano, Employment in the Public Sector, November 2003

1086 Ann-Sofie Kolm and Birthe Larsen, Wages, Unemployment, and the Underground Economy, November 2003

1087 Lars P. Feld, Gebhard Kirchgässner, and Christoph A. Schaltegger, Decentralized Taxation and the Size of Government: Evidence from Swiss State and Local Governments, November 2003

1088 Arno Riedl and Frans van Winden, Input Versus Output Taxation in an Experimental International Economy, November 2003

1089 Nikolas Müller-Plantenberg, Japan’s Imbalance of Payments, November 2003

1090 Jan K. Brueckner, Transport Subsidies, System Choice, and Urban Sprawl, November 2003

1091 Herwig Immervoll and Cathal O'Donoghue, Employment Transitions in 13 European Countries. Levels, Distributions and Determining Factors of Net Replacement Rates, November 2003

1092 Nabil I. Al-Najjar, Luca Anderlini \& Leonardo Felli, Undescribable Events, November 2003

1093 Jakob de Haan, Helge Berger and David-Jan Jansen, The End of the Stability and Growth Pact?, December 2003

1094 Christian Keuschnigg and Soren Bo Nielsen, Taxes and Venture Capital Support, December 2003

1095 Josse Delfgaauw and Robert Dur, From Public Monopsony to Competitive Market. More Efficiency but Higher Prices, December 2003

1096 Clemens Fuest and Thomas Hemmelgarn, Corporate Tax Policy, Foreign Firm Ownership and Thin Capitalization, December 2003 